Review

\title{
Perinatal Brain Injury and Inflammation: Lessons from Experimental Murine Models
}

\author{
Aisling Leavy (1) and Eva M. Jimenez Mateos * \\ Discipline of Physiology, Trinity Biomedical Sciences Institute, School of Medicine, D02 R590 Dublin, Ireland; \\ leavyai@tcd.ie \\ * Correspondence: jimeneze@tcd.ie; Tel.: +353-1896-2710
}

Received: 15 October 2020; Accepted: 2 December 2020; Published: 8 December 2020

check for updates

\begin{abstract}
Perinatal brain injury or neonatal encephalopathy (NE) is a state of disturbed neurological function in neonates, caused by a number of different aetiologies. The most prominent cause of NE is hypoxic ischaemic encephalopathy, which can often induce seizures. NE and neonatal seizures are both associated with poor neurological outcomes, resulting in conditions such as cerebral palsy, epilepsy, autism, schizophrenia and intellectual disability. The current treatment strategies for NE and neonatal seizures have suboptimal success in effectively treating neonates. Therapeutic hypothermia is currently used to treat NE and has been shown to reduce morbidity and has neuroprotective effects. However, its success varies between developed and developing countries, most likely as a result of lack of sufficient resources. The first-line pharmacological treatment for NE is phenobarbital, followed by phenytoin, fosphenytoin and lidocaine as second-line treatments. While these drugs are mostly effective at halting seizure activity, they are associated with long-lasting adverse neurological effects on development. Over the last years, inflammation has been recognized as a trigger of $\mathrm{NE}$ and seizures, and evidence has indicated that this inflammation plays a role in the long-term neuronal damage experienced by survivors. Researchers are therefore investigating the possible neuroprotective effects that could be achieved by using anti-inflammatory drugs in the treatment of NE. In this review we will highlight the current knowledge of the inflammatory response after perinatal brain injury and what we can learn from animal models.
\end{abstract}

Keywords: perinatal brain injury; neonatal encephalopathy; inflammation; hypoxia; hypoxia-ischemia

\section{Neonatal Encephalopathy and Neonatal Seizures}

Neonatal encephalopathy (NE) is a multi-aetiology condition characterised by disturbed neurological function in the first few days of life for babies past 35 weeks of gestation, and comes with a high risk of morbidity and mortality [1]. NE affects an estimated 3 to 5 in 1000 births, with higher incidences observed in lower income countries [1]. Seizures are a common symptom of NE and a neurological emergency in neonates, strongly associated with mortality and the development of significant neurodevelopmental disabilities [2]. Although no consensus has been reached on the definition of neonatal seizures, they are widely accepted to be transient electrographic changes in the brain resultant of excessive, synchronous or abnormal neurological function, presenting with or without clinical signs and occurring in the first 28 days of life for a full term neonate, or before 44 weeks gestational age for a premature neonate [3]. Due to a variety of factors, such as differences in study methodology, national economic status and inter-observer variation, the incidence of neonatal seizures varies markedly, ranging from $0.95-5.0$ in every 1000 births in high income countries [3,4] to incidences as high as 39.5 in 1000 births in low income countries [5]. Mortality from neonatal encephalopathy has decreased in recent decades; however, neurological ramifications are still prevalent [2]. 


\subsection{Aetiology}

A broad range of conditions are responsible for NE onset, such as Hypoxia-Ischemia Encephalopathy (HIE), which is by far the most common cause, placental abnormalities, maternal factors, perinatal infections, metabolic disorders and coagulopathies; and in a small number of cases the exact aetiology is never determined [1]. As the most common cause of NE, HIE is the aetiology of choice when inducing NE in animal studies, particularly in murine and rat models. It is also the most common cause of neonatal seizures, with over half of infants with HIE developing neonatal seizures [6]. For the purpose of this review, we will focus on the hypoxia-ischemia (first characterized by Rice and Vannucci [7]) and hypoxia-only models, the most common causes of NE and the most widely studied.

\section{Classification of Neonatal Seizures in Murine Models of Neonatal Encephalopathy}

Two main types of seizures have been observed in the two main murine models of HIE, the hypoxia-ischemia and hypoxia-only models [8,9]. The first type is defined by a burst of high amplitude spikes occurring at regular intervals and returning to baseline between discharges [8]. The second type is characterized by spike-and wave pattern increasing up to $1-2 \mathrm{~Hz}$, and it is mainly observed after reoxygenation or reperfusion [8].

Both types of seizures have been observed in both models, the hypoxia-ischemia and hypoxia-only models; however, they have different characteristics. In the hypoxic ischemic rat model, the durations of the events of the high amplitude spikes (first type) were on average $220 \mathrm{~s}$ and they started within $30 \mathrm{~min}$ of the ischaemic phase [8]. In contrast, in the mouse hypoxia-only model, the high amplitude spikes lasted for $12.9 \mathrm{~s}$ and they started within the $5 \mathrm{~min}$ of the hypoxic phase [9]. Importantly, in both models the seizure-like activity was associated with changes in behaviour. During the discharges in the rat model, features such as myoclonic jerks, vocalization, head bobbing, and repetitive clonic jerks were observed [8]. In the hypoxia-only mouse model, the behaviours associated with the discharges included circling, swimming, pedalling, spasms and shaking [9]. However, these differences in behavioural seizures could be more related to differences in species than electrographic characteristics of the seizure. Significantly, we do not know how these types of seizures may contribute to the pathology of neonatal seizures; to date, no correlations have been seen between the burst of high amplitude spikes and spike-wave patterns post-insult and molecular markers or neurological outcomes, and how they can contribute to the re-wiring of the brain.

The role of inflammation in neonatal seizures is not fully understood. We know that targeting inflammation before hypoxia reduced the number of seizure events and the duration of seizures $[10,11]$. The mechanism by which this targeting of inflammation reduces seizure activity will require further investigation. Evidence from in vivo experiments supports the role of the cytokine IL-1 $\beta$ signalling in hyper-excitability, as intracerebral injections of IL-1 $\beta$ exacerbate the seizure phenotype of the pro-convulsant agents kainic acid (kainic-acid receptor agonist) and biccuculine (GABA-A receptor antagonist) [12,13]. Furthermore, in transgenic mice, overexpression of IL1-receptor was protective against seizure onset [13]. The underlying mechanism of how IL-1 $\beta$ regulates seizure activity is not fully understood. Evidence from the febrile rat model and adult epilepsy shows that regulation of NMDA receptor activation via IL-1 $\beta$ may be the responsible for the increase seizure activity [12]. Similarly, another pro-inflammatory cytokine, TNF $\alpha$, increases AMPA-receptor density on the membrane, contributing to the hyper-excitability [14].

In summary, evidence for experimental models shows that anti-inflammatory treatment could reduce seizure activity and cytokines may regulate the activity of AMPA and NMDA receptors, but further studies will be necessary to identify the mechanisms underlying those processes in the immature brain. 


\subsection{Current Treatments for Neonatal Encephalopathy}

Babies suffering from neonatal encephalopathy and seizure require urgent treatment to improve their conditions and reduce mortality and morbidity. Currently, the main treatments for neonates with suspected NE are therapeutic hypothermia and phenobarbital $(\mathrm{PhB})$. Therapeutic hypothermia is the only approved non-drug treatment for infants with $\mathrm{NE}$, despite its low response rate. Hypothermia only works in infants with moderate hypoxia and is only effective in reducing the duration of seizures (without reducing the number of ictal events). In the moderate to severe cases (babies suffering from moderate to severe hypoxia), hypothermia is the only therapy option, despite its limited effect, and $50 \%$ of children require a second intervention [6]. Importantly, hypothermia does not improve the neurological outcomes after NE [6].

Phenobarbital (PhB), a positive allosteric modulator of GABA-A receptors, is the first line drug for the treatment of neonatal seizures. $\mathrm{PhB}$ has a response rate of $50 \%$, and exacerbates the seizure phenotype in the remaining cases $[15,16]$. This effect of $\mathrm{PhB}$ is based on its mechanisms of action and the specific nature of the immature neurons. In immature neurons, activation of the GABA-A receptor results in an increase of intracellular $\mathrm{Cl}^{-}$levels. The high intracellular concentration of $\mathrm{Cl}^{-}$causes neurons to depolarise (activate) rather than hyperpolarise- the typical inhibitory effect of GABA in the mature brain [17].

Challenges of Current Drug Treatments in the Clinic

Although PhB has a poor therapeutic profile, it is still recommended as a first-line treatment by the World Health Organisation (WHO), with phenytoin and midazolam as second-line therapies. However, the current anti-convulsant drugs (ACDs) in the clinic present two main risks:

1. Preclinical models have shown that ACDs can induce neurotoxicity and neuronal apoptosis in the immature brain [18-20]. With similar results to those observed in a mouse model of hypoxia, PhB itself induces neuronal damage in neonates; and when given as a treatment for hypoxia-induced seizures, it exacerbates the damage [20].

2. Current ACDs affect neurogenesis, synaptogenesis and synaptic plasticity, resulting in unwanted neuropsychiatric outcomes [20-22]. Indeed, P7 mice pups receiving PhB presented anxiety-like behaviour and detrimental hippocampal function in adulthood [20]. Furthermore, PhB given as a treatment for neonatal seizures does not improve the lasting anxiety-like behaviour and hippocampal-dependent memory of the hypoxic mice [20]. Supporting the pre-clinical animal model, infants treated with $\mathrm{PhB}$ show a strong decrease in cognitive and motor scores at 24 months of age compared to untreated infants [23].

Similarly to current ACDs, poor results were found in the last clinical trial for the treatment of neonatal seizures using the new drug bumetanide (NEMO1; NCT01434225) [24]. Bumetanide, a blocker of the potassium co-transporters (NKCC1 and NKCC2), was observed to reduce seizures in a kainic-acid animal model [18]. Years later, two clinical trials were initiated to establish the safety and efficacy of bumetanide in infants. However, both trials concluded due to the toxic effects of the drug (dehydration, hypotension and permanent hearing loss) and limited evidence of seizure reduction [24]. These studies show the need for understanding the mechanisms underlying neonatal encephalopathy and investigating inflammation as a novel therapeutic target.

\section{Experimental Animal Models of Hypoxia and Hypoxia-Ischemia}

Much research has been conducted to develop different animal models of hypoxia and hypoxia-ischaemia with the aim of finding models which are as reflective as possible of the human condition following neonatal hypoxia. The first model for hypoxia-ischemia in neonates was developed by Rice-Vannucci in 1981 [7]. While this is a very valuable model, it has been associated with high variability in infarct area and symptoms. Modifications of this original model have been developed to reduce variability (Table 1). The most common modifications for this model include levels of oxygen 
administered during the hypoxia treatment period and the postnatal day at which the treatment is administered, resulting in slightly different phenotypes. Importantly, independent of the modifications to the original model by Rice-Vannucci, all of the hypoxia-ischemia models present with the same set of symptoms, including seizure, memory impairment and hyperactivity.

Table 1. Rat and mouse models for hypoxia-ischaemia. The experimental designs employed, along with the resultant behavioural characteristics and $\mathrm{O}_{2}$ levels.

\begin{tabular}{|c|c|c|c|c|}
\hline $\mathrm{O}^{2}$ Levels & Age & Duration & Common Reported Behaviour & References \\
\hline \multicolumn{5}{|c|}{ Rat } \\
\hline $0 \%$ & P0-P11 & $5-30 \mathrm{~min}$ & $\begin{array}{l}\text { Hyperactivity in open field, } \\
\text { impaired memory, } \\
\text { increase anxiety }\end{array}$ & [25-44] \\
\hline $2.5-5 \%$ & P0-P10 & $15-30 \mathrm{~min}$ & $\begin{array}{c}\text { Seizures during hypoxia, } \\
\text { worse water maze performance }\end{array}$ & [44-52] \\
\hline $5-8 \%$ & P7-P10 & $15 \mathrm{~min}-3 \mathrm{~h}$ & $\begin{array}{l}\text { Increase susceptibility to chemical } \\
\text { induced seizures at adulthood }\end{array}$ & [53-62] \\
\hline $10 \%$ & P7-P9 & $30 \mathrm{~min}-6 \mathrm{~h}$ & Hyperactivity in novel object task & [63-65] \\
\hline \multicolumn{5}{|c|}{ Mouse } \\
\hline $0 \%$ & P0-P15 & $20-25 \mathrm{~min}$ & Hyperactivity and seizures & {$[66,67]$} \\
\hline $5 \%$ & P1-P7 & $15 \mathrm{~min}-2 \mathrm{~h}$ & Seizures, impaired learning & {$[9,68]$} \\
\hline
\end{tabular}

More recently, a model of hypoxia-only has been developed in mice, to mimic the mild-moderate neonatal encephalopathy more commonly caused by birth asphyxia. Similarly to the hypoxia-ischemia murine models, different levels of oxygen, ages and durations have been used (Table 2).

Table 2. Experimental design for the hypoxia-only mouse models, along with the resultant behavioural phenotypes.

\begin{tabular}{|c|c|c|c|c|c|c|}
\hline Species & $\begin{array}{l}\mathrm{O}^{2} \text { Partial } \\
\text { Pressure }\end{array}$ & $\begin{array}{c}\text { Age } \\
\text { (Postnatal Day) }\end{array}$ & $\mathrm{T}\left({ }^{\circ} \mathrm{C}\right)$ & $\begin{array}{l}\text { Duration of } \\
\text { Hypoxia }\end{array}$ & $\begin{array}{c}\text { Reported Behavioural } \\
\text { Phenotype }\end{array}$ & References \\
\hline C57 Mouse & $0 \%$ & P3-15 & RT & $20 \mathrm{~min}$ & $\begin{array}{l}\text { Electrographic seizures } \\
\text { without clinical } \\
\text { manifestations. }\end{array}$ & [67] \\
\hline Mouse & $0 \%$ & P0 & $33,37,39$ & $25 \mathrm{~min}$ & $\begin{array}{c}\text { Both open-field } \\
\text { stress-induced and } \\
\text { spontaneous motor activity } \\
\text { reduced. Hyperactive in } \\
\text { the plus maze test. } \\
\text { Behavioural disturbances } \\
\text { were prevented by the body } \\
\text { temperature of } 33^{\circ} \mathrm{C} \text {. }\end{array}$ & [66] \\
\hline C57 Mouse & $5 \%$ & P7 & 34 & $15 \mathrm{~min}$ & $\begin{array}{l}\text { Seizures in pups, reduced } \\
\text { curiosity in novel object } \\
\text { test, weight loss. }\end{array}$ & [9] \\
\hline Mouse & $5 \%$ & P1 & - & $2 \mathrm{~h}$ & $\begin{array}{l}\text { Melatonin improved } \\
\text { learning and memory in the } \\
\text { Morris water maze. }\end{array}$ & [68] \\
\hline
\end{tabular}

Nevertheless, the symptoms observed in the hypoxia-ischemia and the hypoxia-only models are related to seizure, memory impairment and hyperactivity, demonstrating that similar mechanisms are probably activated independently of the original insult. Interestingly, the model outlined by Wang and colleagues [68] (Table 2) noted that treatment with melatonin post-hypoxia improved performance in the Morris water maze regarding learning and memory, which could possibly have been due to the melatonin having an anti-inflammatory effect [68]. 
In summary, we can conclude that the hypoxia-ischaemia and the hypoxia-only models have similar long-lasting neurological outcomes, including hyperactivity and memory impairment. They also show that the dose of oxygen administered, along with the duration of the treatment, play integral roles in the behavioural characteristics seen post-hypoxia.

\section{Inflammation in Neonatal Encephalopathy}

Neuroinflammation caused by hypoxia or hypoxic ischemia during the perinatal period contributes to increased risk for neurological deficits and long-term disabilities in children [69]. Inflammation induced by injury results in activation of the resident and peripheral immune cells and production of cytokines. In recent years, inflammation has been implicated in neonatal brain damage following perinatal stress. Induction and activation of microglia and astrocytes are hallmarks of neuroinflammation, which occurs in response to hypoxia and hypoxic ischemia in neonates [11,70]. Studies have shown that exposure of the neonatal brain to hypoxia, thereby causing an inflammatory response, is associated with long-lasting changes to neuronal morphology within the hippocampus and other vulnerable structures of the brain [71]. Circulating cytokines and neuroimmune cells such as microglia are the targets of several studies that are investigating the potential use of these components as biomarkers for neonatal brain injury. Additionally, targeting inflammation improves acute and long-lasting effects after hypoxia and hypoxic ischemia in mice [11,70].

Studies into the inflammatory response post-hypoxia have revealed that HIE is a sexually dimorphic disease, with male infants being far more vulnerable to ischaemic insults. Male infants are also significantly more at risk of suffering from long-term cognitive deficits when compared to female infants with comparable brain damage [72]. In fact, the microglial anti-inflammatory response was more robust in females than in males [72]. More infiltration of peripheral lymphocytes, along with upregulated TNF $\alpha$ and IL10, were observed in males when compared with females. It was also noted that neurogenesis was more highly induced in female HIE brains versus male HIE brains. The conclusions drawn from this study were that the pro- and anti-inflammatory responses are indeed dichotomous with respect to sex, which is integral to the sex-specific chronic HIE outcomes, and that increased induction of neurogenesis in females also contributes to this sex-specific difference [72].

It has been long established that infants born prematurely are more vulnerable to the effects of asphyxia and developing adverse sequelae. Acute asphyxia at birth followed by HIE is more frequently seen in infants born prematurely than infants born at term, and is highly associated with the onset of adverse neurological outcomes [73]. Several studies have found that while HIE still only occurs in a minority of preterm births, it is a significant contributor to severe disability [74-76]. Mild HIE in preterm infants can result in white matter injury, even in the absence of abnormalities in neurological exams at discharge [75]. The pattern of injury onset can be more prolonged in preterm infants; in some patients who develop cerebral palsy, there are no white matter lesions; however, long-term studies showed that it may be delayed onset demyelination [77]. As a result of this white matter injury, even in mild cases, the resultant adverse outcomes can be attributed to impaired global and regional connectivity between cortical and subcortical grey matter structures [78]. Evidence has also shown a correlation between preterm births and stunted cortical plasticity in adolescents [79]. Extensive evidence from preclinical studies has strongly implicated CNS and peripheral immune responses in the pathogenesis of HIE and preterm brain injury [69]. Various clinical and human post-mortem studies have shown that chronically upregulated systemic and CNS cytokines and gliosis show strong associations with adverse neurological outcomes [80,81]. Evidence has shown that systemic upregulation of TNF $\alpha$ and IL1 $\beta$ in premature infants is associated with impaired neural functions in the first $72 \mathrm{~h}$ of life, followed by cognitive impairment at 2 to 3 years of age [81].

It is clear from both human and animal studies that inflammation and the immune response are key to many aspects of the pathogenesis and pathophysiology of HIE and neonatal brain damage. However, further studies will be necessary to elucidate the underlying mechanisms associated with neonatal brain damage. 


\subsection{Pathogen-Associated Molecular Patterns (PAMPS) and Damage-Associated Molecular Patterns (DAMPS)}

Pathogen-associated molecular patterns, or PAMPs, are normally conserved microbial products such as lipopolysaccharides which activate pattern recognition receptors (PRRs. such as Toll-like receptors (TLRs)) after a bacterial or viral infection. PRR signalling pathways have been shown to initiate cascades that lead to immune cells recruitment to the site of an infection [82]. In contrast to this, danger-associated molecular patterns, or DAMPs, are molecular patterns associated with sterile inflammation, or inflammation instigated without introduction of a pathogenic microbe, as seen after neuronal necrosis. These molecular patterns are released in response to tissue damage, with the same innate pattern recognition systems used in the detection of microbes initiating this sterile inflammatory response [82]. This inflammatory response, followed by tissue repair, is dependent on microglia migration to and from the site of injury [83]. Studies show that DAMPs and PAMPs induce distinctly different inflammatory responses in the neonatal brain (Figure 1). Lalancette-Hebert and colleagues [84] studied the difference between these responses with respect to toll-like receptor 2 (TLR2) expression. It was found that a neonatal mouse model of infection induced TLR2 expression and secretion of inflammatory mediators. Contrasting results were seen in the two neonatal mouse models of sterile inflammation (IL-1 $\beta$ injection and MCAO), which showed decreased induction of TLR2 and reduced production of inflammatory cytokines [84]. This study highlights the existence of scenario-specific innate immune responses, depending on the presence of either infections or sterile inflammation, and the necessity of looking for specific therapeutic strategies depending on the original insult. In the following sections we will examine the activation of the most studied family of receptors in hypoxia and hypoxia-ischemia murine animal models.

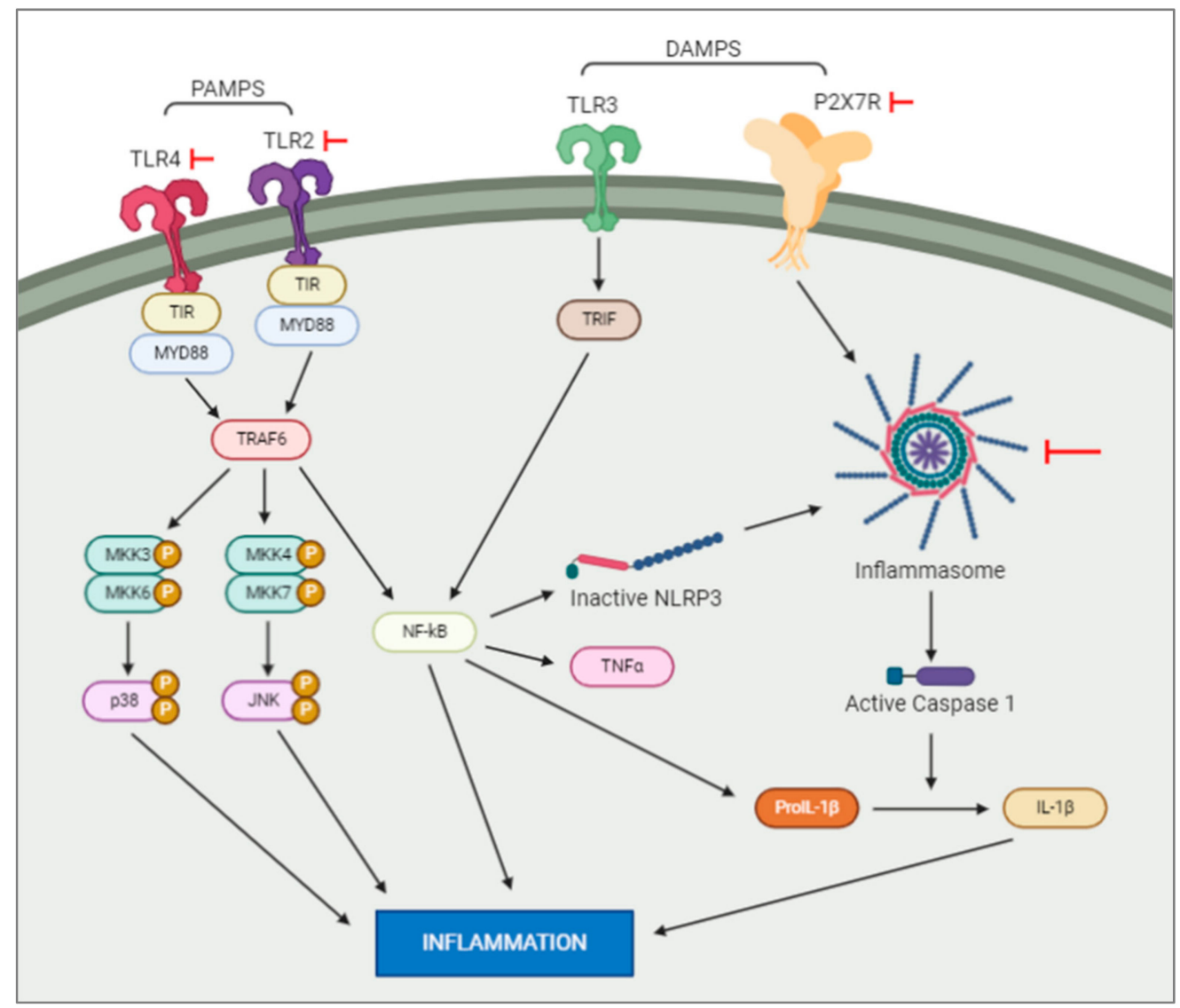

Figure 1. Intracellular pathways activated by DAMPS and PAMPS. DAMPS and PAMPS will bind to the membrane receptors, e.g., TLR and P2X7. This activation will trigger a series of intracellular events resulting in an increase of inflammation. Note: the red arrows represent experiments which have blocked the actions of the elements they are pointed at. 


\subsection{Toll-Like Receptors in Neonatal Encephalopathy}

Upregulation of pattern-recognition receptors, such as TLRs, has been shown after perinatal brain injury. The Toll like receptor (TLR) family consists of nine subtypes (TLR1-9). They recognize a variety of pathogen-associated molecular patterns (PAMPS), including LPS, bacterial DNA and double stranded RNA. The role of TLR in perinatal brain injury has been extensively studied. TLR1, 2 and 7 are up-regulated $24 \mathrm{~h}$ after hypoxic ischemia in pups. TLR5 is downregulated and TLR3, 4, 6,8 and 9 do not change expression. Interestingly, when KO mice for TLR 1 and 2 were subjected to hypoxic ischemia, TLR2 KO improved the infarct volume after hypoxic ischemia, but TLR1 KO did not have an effect. This data showed that TLR2 plays a role in initiating inflammation after perinatal brain injury $[85,86]$. Supporting this data, the use of Candesartan Cilexetil, a drug which reduces levels of TLR2, has been shown to improve neuronal damage after hypoxia in mice, and also improve the long-lasting neurological outcomes [11]. Importantly, the response of TLR2 to sterile (e.g., HI) or non-sterile inflammation (e.g., LPS to mimic bacterial infection) differs on the pre-clinical model [84]. Suggesting that, deeper knowledge of the pathways underlying TLR2 is important for developing new pharmacological treatments.

TLR4, another receptor implicated in DAMP and PAMP functions, has also been studied, due to observations that its inhibition has neuroprotective effects in neonatal brain damage [87]. TLR4 inhibition shortly after injury reduced activation of hippocampal glial cells improved hippocampal neuronal loss later in life and resulted in less severe long-term neurological outcomes [87]. These studies, by targeting receptors which mediate the effects of DAMPs and PAMPs, show the important roles played by these molecules in the mediation of the neuroinflammatory response following hypoxic ischaemic brain injury. Further studies are needed to fully understand these interactions in the neonatal brain post-injury.

\subsection{Purinergic Signalling Activation after Neonatal Encephalopathy}

Extracellular adenosine triphosphate (ATP) is a typical DAMP which acts as a glio- and neurotransmitter in the CNS to modulate functions such as brain excitability and neuroinflammation [88]. It is considered to be a co-transmitter in most neurons of the central and peripheral nervous system, and is released from astrocytes and neurons to act as either a co-transmitter or a sole transmitter [89]. The P2X class of ionotropic receptors, made up of seven distinct receptors, mediates the rapid effects of extracellular ATP by gating sodium and calcium entry into cells [90]. The P2X7 receptor (P2X7R) modulates cytokine production, glial activity and neurotransmitter release following brain injury [90]. P2X7R activation is seen in instances of pathologically high extracellular ATP levels, the likes of which are seen during seizures and brain injury. Downstream signalling of the P2X7R results in microglia activation and the release of interleukin $1 \beta$ (IL-1 $\beta$ ), which is a pro-convulsive inflammatory cytokine [91-93]. Evidence has shown that P2X7R is expressed by neurons and acts as a modulator of neurotransmitter release [94,95]. Similarly, each member of the P2Y class of eight purinergic metabotropic receptors is stimulated by ATP, and they are generally associated with slower presynaptic functions, and mediation of trophic signalling in cell differentiation, proliferation and death during development [89]. During epileptic seizures, large quantities of nucleotides enter the extracellular space from neurons and glia due to metabolic limitations [96]. These activate the P2X and P2Y receptors, including P2X7 and P2Y1, which are expressed on both embryonic and adult neural progenitor cells (NPCs). These two receptors regulate NPC functions, causing necrosis and apoptosis, and proliferation, differentiation and migration [97,98]. In a study by Rozmer and colleagues [99], patch-clamp recordings were carried out on hippocampal brain slices from neonate and adult transgenic nestin reporter mice which underwent pilocarpine-induced status epilepticus. This study detected the presence of P2X7R in NPCs in the subgranular zone of the dentate gyrus. Upon activation of these receptors, inward current was recorded near the resting membrane potential of the NPCs. P2Y1 receptor activation, on the other hand, initiated outward current close to the reverse potential of the P2X7R current [99]. It was also noted that the sensitivity of these two receptors was invariably increased. In this model, status epilepticus 
was preceded by a latency of 5 days after treatment with pilocarpine, and recurrent epileptic fits occurred during this period. Blockade of central P2X7Rs increased the number of seizures experienced, along with their severity. Rozmer and colleagues [99] hypothesised from these results that P2Y1 receptors increase proliferation and migration of NPCs, while P2X7R mediated necrosis and apoptosis may counter these effects, which would otherwise result in chronic recurrent epileptic seizures.

Experiments have been carried out to block the P2X7R in order to fully understand the role of this receptor in perinatal stress and subsequent brain injury. P2X7R is over-expressed in a neonatal mouse model of global hypoxia, and targeting of P2X7R with A-438079, a receptor antagonist of P2X7R, can reduce the number of post-hypoxia neonatal seizures [10]. These results corroborated an earlier study by Mesuret and colleagues [100], which used the same inhibitor to investigate the effects of P2X7R antagonism on early-life seizures in rats. This study also found that P2X7R blockade by A-438079 improved neonatal seizures, and suggested A- 438079 could be used as a treatment for neonatal seizures or paediatric status epilepticus [100]. Similarly, Brilliant Blue G (BBG), a P2X7R-specific inhibitor, inhibits LPS-induced IL-1 $\beta$ release in mouse models of intrauterine inflammation [101], resulting in perinatal brain injury. P2X7R blockade resulted in reduced preterm birth rates, dendritic arborisation and density of cortical neurons, and improved performance for offspring in neuromotor tests [101]. These results supported the role of IL- $1 \beta$ as a key mediator of perinatal brain injury. Further studies corroborated the neuroprotective effects of P2X7R blockade, with da Silva and colleagues [102] showing that in a neonatal rat model of LPS-induced inflammation, pharmacologic blockade of P2X7R in the neonatal period using BBG has neuroprotective effects that persist into adulthood [102].

\subsection{Cytokines and Chemokines in Neonatal Encephalopathy}

Cytokines and chemokines, such as tumour necrosis factor $\alpha$ (TNF $\alpha)$ and interleukin $1 \beta$ (IL1 $\beta)$, are released by microglia and astrocytes in response to hypoxic ischaemic injury, amplifying inflammatory cascades that recruit monocytes and neutrophils to the site of injury [103]. Studies have demonstrated an association between more adverse outcomes following perinatal brain damage and pro-inflammatory cytokines, such as TNF $\alpha$, IL1 $\beta$ and IL6 [104]. These cytokines are released by astrocytes, neurons and microglia and are associated with HIE. A study by Liu and colleagues [104] demonstrated this by studying the peripheral blood levels of TNF $\alpha$ and IL1 $\beta$ of human neonates with HIE and control neonates. It was found that neonates with HIE consistently had higher levels of TNF $\alpha$ and IL1 $\beta$, and there was a positive correlation between IL1 $\beta$ levels and HIE severity [104]. Chemokines also play a pivotal role in the inflammatory response following NE or HIE, due to their roles in inflammatory cell trafficking and leukocyte activation [105]. When HIE is modelled in rats [106], upregulation of alpha-chemokines such as macrophage inflammatory protein 2 (MIP2) and beta-chemokines such as MIP1 $\alpha$, MIP1 $\beta$ and CCL 5 is induced, followed by the expression of lymphocyte markers in the site of infarction. This inflammatory response persisted beyond the neonatal period in this rat model, indicating that this acute inflammation may trigger a chronic inflammatory response [106].

\subsubsection{Interleukin $1 \beta$, IL1 $\beta$}

There is no doubt that IL-1 $\beta$ levels are increased after neonatal brain injury. Hypoxic ischemia and hypoxia-only both cause acutely increased IL1 $\beta$ levels after the original insult $[10,11]$. However, it is not clear whether this increase of IL1 $\beta$ is sustained over time. Results from the hypoxia-ischemia model showed increases in IL1 $\beta 6$ days and 14 days after reperfusion. However, in the hypoxia-only model, IL1 $\beta$ levels returned to normal levels after $72 \mathrm{~h}$ [11].

Supporting the role of IL1 $\beta$ in ischemia, administration of type 1 interleukin receptor (IL1R1) antagonist or blocking antibodies ameliorates damage induced by excitotoxicity and/or ischemia. IL1 $\beta$ knockdown by lentivirus in vivo can also improve the damage caused by neonatal HI [10]. Further analysis will be necessary if these results can be reproduced on the hypoxia-only model where the induction of IL1 $\beta$ is transient. 


\subsubsection{Interleukin-6, IL6}

IL6 has been shown to have a dual function, having beneficial and/or detrimental effects depending on the context. In adult rodents, IL6 has an inflammatory effect in the acute phase, but during the chronic phase, IL6 acts as a neurotrophic factor [70].

In the neonatal brain, IL6 is increased transiently in the first hours after ischemia. Blockers of IL6 have a neuroprotective effect after the ischemic insult. However, no differences were observed between the ipsilateral (hypoxic-ischemic side) and the contralateral side (hypoxic only side), making it difficult to determine the role of IL6 in the neonatal brain. Further studies will be necessary to fully elucidate the role of IL6 during neonatal brain injury.

\subsubsection{Tumour Necrosis Factor, $\mathrm{TNF} \alpha$}

It is clear that TNF $\alpha$ is increased after neonatal brain injury; however, its role is not clear. TNF $\alpha$ binds to TNF-R1 and TNF-R2. Activation of TNF-R1 activates a caspase signalling pathway, resulting in cell death. In contrast, activation of TNF-R2 induces cell proliferation via the survival Akt signalling pathway. In neonatal hypoxic ischemia in rats, an increase of TNF-R1 has been observed in oligodendrocytes, suggesting that TNF $\alpha$ may play a role in the apoptosis and delayed myelination observed in neonatal brain injury. The role of TNF $\alpha$ will require further analysis to clarify its beneficial or detrimental effect [107].

\section{Contributions of Central and Peripheral Cells to Neonatal Encephalopathy}

Both central and peripheral immune cells contribute to the damage induce after hypoxia-ischemia and hypoxia. In this section, we will discuss how the different cells types contribute to the damage after NE (Figure 2).

\subsection{Microglia}

Microglia are dynamic cells that maintain neurons and neural circuits, and are responsible for mediating the immune response within the brain once activated. When microglia are activated following injury, their roles include cytokine and chemokine release, phagocytosis and antigen presentation. Microglia undergo morphological transformation into their activated state following HIE. Microglial aggregation and activation have been established as pathological markers for HIE, as activated microglia are believed to contribute to HIE and excitotoxic injury [70]. Winerdal and colleagues [107] investigated long-term local and systemic inflammation in a mouse model of HIE. The study showed that in the months following the initial HIE event, the mice showed elevated activation of local and systemic inflammatory response, and suggested that this prolonged inflammation also contributes to potential brain damage following HIE [107]. Another study by Serdar and colleagues [83] investigated microglial phenotypes in the early stages of hypoxic-ischaemic brain injury using a rat model of inflammation-sensitised HI brain injury. This study identified microglia as key mediators of the inflammatory response following injury, with a predominantly pro-inflammatory phenotype adopted in the $24 \mathrm{~h}$ post-hypoxia [83]. Studies of this nature open doors for new treatment options to be explored which target microglial processes and morphology to prevent the injurious inflammatory response post-hypoxia.

\subsection{Astrocytes}

Astrocytes are the most abundant of the glial cells in the mammalian brain, and provide many functions within the CNS, including regulation of the extracellular environment, removing excess neurotransmitters and provision of metabolic and structural support for neurons $[108,109]$. Excessive glutamate release occurs following HIE, leading to overstimulation of the glutamate receptor $\mathrm{N}$-methyl-D-aspartate (NDMA). This overstimulation triggers the excito-oxidative injury cascade by causing excessive Ca2+ influx to the cytosol, resulting in apoptotic cell death in neurons [110]. 
Contributing to the pathology after hypoxic ischemia, astrocytes have a diminished capacity for glutamate uptake caused by mitochondrial failures [111]. Interestingly, mitochondrial failure was found to be a sexually dimorphic; male pups have a stronger acute response than females, and female pups have a longer reduction in function than males [111].

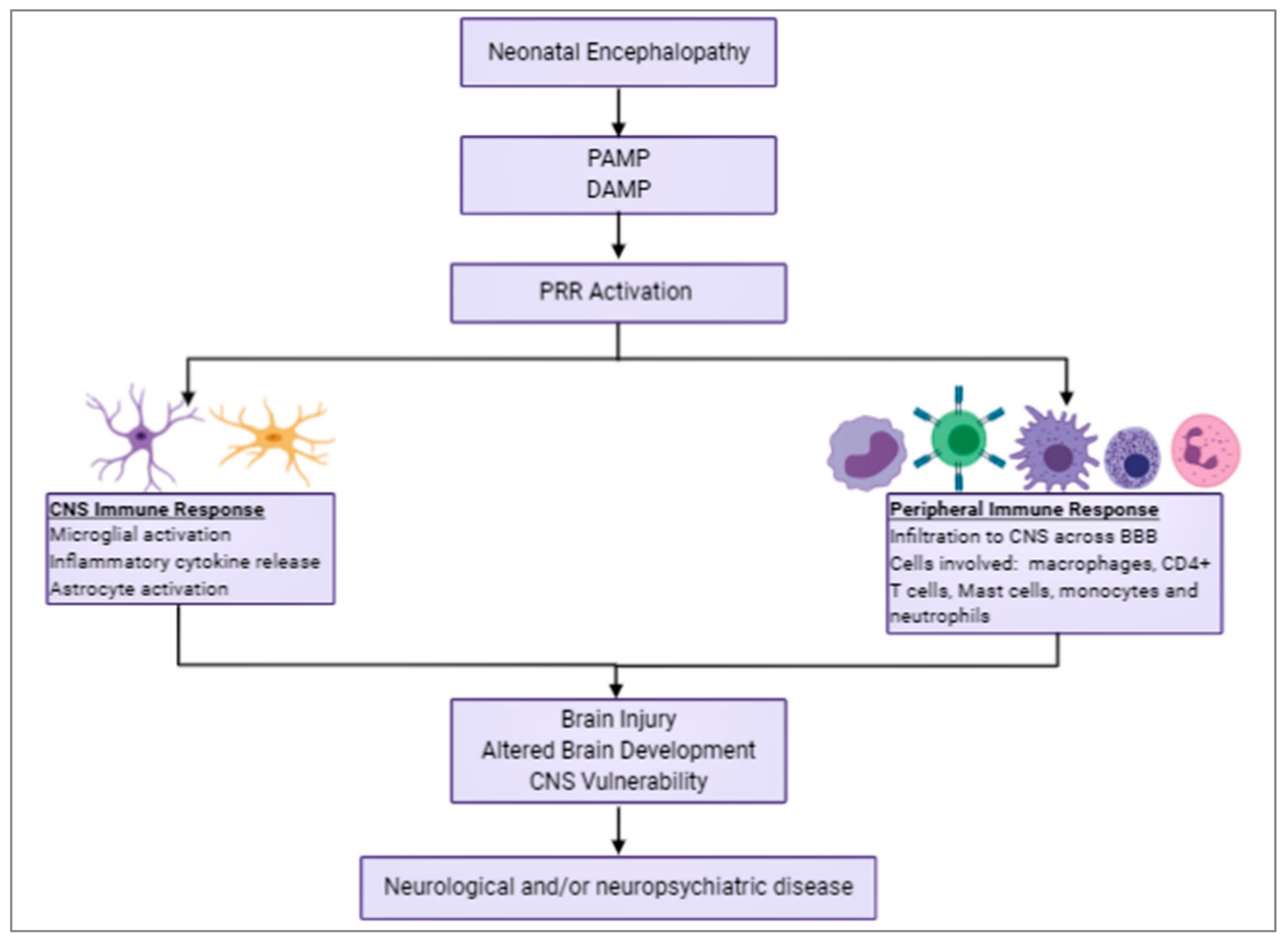

Figure 2. Summary of the inflammatory processes that occur following neonatal encephalopathy (NE), highlighting the cell types involved from both the CNS and peripheral immune response along with the ramifications of NE that persist long after this inflammatory response abates.

Wang and colleagues [112] investigated the role of TRVP1 translocation in astrocytic membranes at the onset of HIE-induced epilepsy, potentially identifying this receptor channel protein as a therapeutic target. TRVP1 is a member of the vanniloid transient receptor potential (TRVP) channel family, and is a $\mathrm{Ca}^{2+}$ permeable channel, previously studied for its role as a pain receptor in sensory neurons [113]. Using a mouse model, this study ascertained the importance of TRVP1 in the promotion of astrocyte migration, which in turn encourages the infiltration of pro-inflammatory cytokines to the vicinity of neurons and promotes the onset of epilepsy. The results of this study rationalise the potential of TRVP1 as an anti-epileptogenic therapeutic target after HIE [112].

Evidence implicates astrocytes at the onset of damage post-HIE; however, astrocytes and their responses to certain cytokines are also associated with having certain neuroprotective effects. IL-10 released from astrocytes suppressed neuronal apoptosis in response to HIE via the TLR2/NFkB pathway in a rat model of hypoxia-ischemia [114]. Similarly, the astrocyte-derived IL-33 following HIE is upregulated in the first $24 \mathrm{~h}$ post-HIE, and the ST2 receptor, the receptor for IL-33, was shown to be upregulated in astrocytes post-HIE [115]. Importantly, exogenous delivery of IL-33 via intraperitoneal injection alleviated the resultant brain injury 7 days post-HIE. Conversely, deficiency of the ST2 receptor exacerbated brain damage and neurological sequelae post-HIE. When mice were treated with IL-33 post-HIE, astrocyte apoptosis was attenuated, and astrocyte response was improved through the ST2 
pathway, including released neurotrophic factors essential for neuronal survival against oxygen and glucose deprivation.

The role of IL-6 is HIE is not clear (see section above, "Interleukin-6, IL6"); however, IL-6 has been found to be neuroprotective after HIE due to its effects on astrocytes. Overexpression of IL-6 via mesenchymal stem cell transplantation alleviates neurological sequelae following HIE. The mechanism of this neuroprotective action is not fully understood; however, it has been observed that IL-6 suppresses apoptosis of injured astrocytes [116] and reduces proliferation of reactive astrocytes induced by HIE [117].

\subsection{Oligodendrocytes}

Neurons and oligodendrocytes during development have high metabolic rates, making them more vulnerable to anoxia. During development, grey and white matter injuries have been associated with sub-acute and chronic hypoxia-ischemia. Importantly, white matter injury is common in pre-term babies; however, results are contrasting in term babies, in whom white matter injury has been linked with chronic hypoxia, but not in areas of high metabolic activity like the thalamus [118]. These differences in white matter injury in pre-term and term babies may be a reflection on the maturation of oligodendrocytes in pre-term and full-term babies [69].

The degree of damage on premature neonates correlates with a predominance of late oligodendrocytes progenitor cells (OPCs) in the immature brain. The observed hypomyelination may be due to the death of OPC, stopping oligodendrocyte maturation, and depletion of the number of OPCs [119,120].

It is not clear what the mechanism underlying the damaging of OPCs is in premature babies; evidence has shown that OPCs express the calcium-permeable AMPA receptor. Glutamate activates the AMPA receptor, inducing an increase of intracellular $\mathrm{Ca}^{2+}$, resulting in Bax activation, translocation of Bax to the mitochondria and activation of caspase-3 and cell death [121].

Supporting the role of inflammation in myelinations, intraperitoneal injections of IL-1 $\beta$ in the first days of life results in an increase in unmyelinated fibres. Additionally, IL-6 could also induce cell cycle withdrawal and maturation of OPCs [122]. In fact, transgenic mice which overexpressed IL-6 had severe neurological symptoms, including ataxia, tremor and seizures; however, white matter damage was not demonstrated [123].

\subsection{Peripheral Immune Cells}

Peripheral immune cells can cross the blood-brain barrier (BBB) via a number of BBB portals, namely, the parenchymal blood vessels, the meningeal vessels and the choroid plexus [124]. In neonates, low levels of monocytes, macrophages and $\mathrm{CD}^{+}{ }^{+} \mathrm{T}$-cells exist in the CSF of healthy neonates for what is believed to be immune surveillance purposes [125]. In response to insults such as HIE, the immature CNS, as seen in neonates, upregulates a number of chemoattractant molecules in response to HIE, including CCL2, CCL3 and CCL7, resulting in recruitment of monocytes from the bone marrow, and CXCL1, responsible for recruiting monocytes to inflamed tissues $[126,127]$. These guide peripheral immune cells towards the CNS, and as a result, a number of peripheral immune cells infiltrate the CNS and accumulate within.

Accumulations of neutrophils in the brain's blood vessels following HIE have been observed in numerous clinical studies and experimental models; however, they tend to remain largely contained within the blood vessels $[106,128]$. It has been hypothesised that neutrophils are implicated in an early-phase temporary impairment of red blood cell and oxygen flow [124].

Studies of mast cells in neonatal HIE have found that these cells excessively express transforming growth factor beta (TGF- $\beta$ ), which encourages the onset of excitotoxic brain injury [129]. Mast cell numbers were also seen to increase in the acute HIE response, with rapid degranulation and release of TNF- $\alpha$ also being observed. Furthermore, inhibition of mast cell degranulation and activation had neuroprotective effects $[130,131]$. 
The role of monocytes has been extensively studied in HIE in preclinical models [132]. Significant numbers of peripherally derived MDMs infiltrated and accumulated in the immature CNS post-HIE, with the majority of this invasion occurring one day post-HIE. They also ascertained that inhibition of this accumulation of myeloid cells was neuroprotective in male but not female neonatal mice. This study demonstrated the infiltration of peripheral monocytes, while also supporting the sexually dimorphic nature of the inflammatory response post-HIE.

$\mathrm{T}$ cells generally do not cross the BBB; however, higher $\mathrm{CD}^{+} \mathrm{T}$ cell numbers is a characteristic of the post-HIE immune response [106]. Maximal $\mathrm{CD}^{+} \mathrm{T}$ cell numbers were observed 7 days post-HIE, and these cells persisted within the CNS up to 35 days post-HIE. This recruitment of CD4+ T cells attract the recruitment of CD8+ T cells in a rat model of HIE. Importantly, these cells persisted in the CNS 3 months post-HIE [107]. Supporting this data, Albertsson and colleagues [133] demonstrated in a mouse model that this CD4+ influx was biphasic, with this influx occurring 1 day and 7 days post-HIE.

Immune cell infiltration has been shown to have an important role in neonatal brain injury, with elements from both the innate and adaptive immune systems recruited to the CNS following neonatal HIE. This also shows the complexity of the inflammatory response that is triggered in both the acute and chronic responses to HIE.

\section{Conclusions}

The merits of using anti-inflammatory drugs as treatments for neonatal encephalopathy have been extensively studied. Mounting evidence has shown that the inflammatory components within the brain, such as microglial activation and cytokine signalling, play pivotal roles in the pathophysiology of HIE and neonatal seizures [11,71]. Several studies have investigated the effects of anti-inflammatory drugs as treatments for HIE and neonatal seizures, particularly small molecule drugs, as these are more likely to successfully cross the blood-brain barrier. Thus far, these studies have shown the beneficial neuroprotective effects of these anti-inflammatory molecules in animal models [10,11]. However, several questions remain unanswered regarding the nature of the main inflammatory response induced by perinatal stress. Research so far has been unable to ascertain whether the activated immune cells seen in the post-hypoxia response are central immune cells or are recruited from peripheral tissues. Additionally, research into the effects of anti-inflammatory therapeutics has yet to determine whether the long-term outcomes resulting from neonatal brain damage can be improved by targeting inflammation weeks after the original insult. Various inflammatory pathways have been discussed in this review, particularly the TLR and purinergic pathways which are dictated by DAMPS and PAMPS activation. Those elements which have not been blocked or antagonised by experiments are possible targets for future studies, so that we might fully understand their roles in the post-hypoxia ischemia response.

Author Contributions: A.L. and E.M.J.M. wrote and edited the manuscript. All authors have read and agreed to the published version of the manuscript.

Funding: This review was supported by Science Foundation Ireland (13/SIRG/2114) and Welcome Trust Institutional Strategic Plan.

Conflicts of Interest: The authors declare no conflict of interest.

\section{References}

1. Aslam, S.; Strickland, T.; Molloy, E.J. Neonatal encephalopathy: Need for recognition of multiple etiologies for optimal management. Front. Pediatr. 2019, 7. [CrossRef] [PubMed]

2. Yıldız, E.P.; Tatlı, B.; Ekici, B.; Eraslan, E.; Aydınlı, N.; Çalışkan, M.; Ozmen, M. Evaluation of etiologic and prognostic factors in neonatal convulsions. Pediatric Neurol. 2012, 47, 186-192. [CrossRef] [PubMed]

3. Pellegrin, S.; Munoz, F.M.; Padula, M.; Heath, P.T.; Meller, L.; Top, K.A.; Wilmshurst, J.; Wiznitzer, M.; Das, M.K.; Hahn, C.D.; et al. Neonatal seizures: Case definition \& guidelines for data collection, analysis, and presentation of immunization safety data. Vaccine 2019, 37, 7596-7609. [PubMed] 
4. Vasudevan, C.; Levene, M. Epidemiology and aetiology of neonatal seizures. Semin. Fetal Neonatal Med. 2013, 18, 185-191. [CrossRef]

5. Mwaniki, M.K.; Mathenge, A.; Gwer, S.; Mturi, N.; Bauni, E.; Newton, C.R.; Berkley, J.A.; Idro, R. Neonatal seizures in a rural Kenyan District Hospital: Aetiology, incidence and outcome of hospitalization. BMC Med. 2010, 8, 16. [CrossRef]

6. Boylan, G.B.; Kharoshankaya, L.; Wusthoff, C.J. Seizures and hypothermia: Importance of electroencephalographic monitoring and considerations for treatment. Semin. Fetal Neonatal Med. 2020, 20, 103-108. [CrossRef]

7. Rice, J.E., 3rd; Vannucci, R.C.; Brierley, J.B. The influence of immaturity on hypoxic-ischemic brain damage in the rat. Ann. Neurol. 1981, 9, 131-141. [CrossRef] [PubMed]

8. Morin, L.; Enderlin, J.; Leger, P.-L.; Perrotte, G.; Bonnin, P.; Dupuis, N.; Baud, O.; Charriaut-Marlangue, C.; Auvin, S. Different response to antiepileptic drugs according to the type of epileptic events in a neonatal ischemia-reperfusion model. Neurobiol. Dis. 2017, 99, 145-153. [CrossRef]

9. Rodriguez-Alvarez, N.; Jimenez-Mateos, E.M.; Dunleavy, M.; Waddington, J.L.; Boylan, G.B.; Henshall, D.C. Effects of hypoxia-induced neonatal seizures on acute hippocampal injury and later-life seizure susceptibility and anxiety-related behavior in mice. Neurobiol. Dis. 2015, 83, 100-114. [CrossRef]

10. Rodriguez-Alvarez, N.; Jimenez-Mateos, E.M.; Engel, T.; Quinlan, S.; Reschke, C.R.; Conroy, R.M.; Bhattacharya, A.; Boylan, G.B.; Henshall, D.C. Effects of P2X7 receptor antagonists on hypoxia-induced neonatal seizures in mice. Neuropharmacology 2017, 116, 351-363. [CrossRef]

11. Quinlan, S.; Merino-Serrais, P.; Di Grande, A.; Dussmann, H.; Prehn, J.H.M.; Ní Chonghaile, T.; Henshall, D.C.; Jimenez-Mateos, E.M. The anti-inflammatory compound candesartan cilexetil improves neurological outcomes in a mouse model of neonatal hypoxia. Front. Immunol. 2019, 10, 1752. [CrossRef] [PubMed]

12. Vezzani, A.; Conti, M.; De Luigi, A.; Ravizza, T.; Moneta, D.; Marchesi, F.; De Simoni, M.G. Interleukin-1 $\beta$ immunoreactivity and microglia are enhanced in the rat hippocampus by focal Kainate application: Functional evidence for enhancement of electrographic seizures. J. Neurosci. 1999, 19, 5054-5065. [CrossRef] [PubMed]

13. Vezzani, A.; Moneta, D.; Conti, M.; Richichi, C.; Ravizza, T.; Luigi, A.D.; De Simoni, M.G.; Sperk, G.; Andell-Jonsson, S.; Lundkvist, J.; et al. Powerful anticonvulsant action of IL-1 receptor antagonist on intracerebral injection and astrocytic overexpression in mice. Proc. Natl. Acad. Sci. USA 2000, 97, 11534-11539. [CrossRef] [PubMed]

14. Stellwagen, D.; Beattie, E.C.; Seo, J.Y.; Malenka, R.C. Differential regulation of AMPA receptor and GABA receptor trafficking by tumor necrosis factor-alpha. J. Neurosci. 2005, 25, 3219-3228. [CrossRef]

15. Spagnoli, C.; Seri, S.; Pavlidis, E.; Mazzotta, S.; Pelosi, A.; Pisani, F. Phenobarbital for neonatal seizures: Response rate and predictors of refractoriness. Neuropediatrics 2016, 47, 318-326. [CrossRef]

16. Donovan, M.D.; Griffin, B.T.; Kharoshankaya, L.; Cryan, J.F.; Boylan, G.B. Pharmacotherapy for neonatal seizures: Current knowledge and future perspectives. Drugs 2016, 76, 647-661. [CrossRef]

17. Al-Muhtasib, N.; Sepulveda-Rodriguez, A.; Vicini, S.; Forcelli, P.A. Neonatal phenobarbital exposure disrupts GABAergic synaptic maturation in rat CA1 neurons. Epilepsia 2018, 59, 333-344. [CrossRef]

18. Forcelli, P.A.; Kim, J.; Kondratyev, A.; Gale, K. Pattern of antiepileptic drug-induced cell death in limbic regions of the neonatal rat brain. Epilepsia 2011, 52, e207-e211. [CrossRef]

19. Torolira, D.; Suchomelova, L.; Wasterlain, C.G.; Niquet, J. Phenobarbital and midazolam increase neonatal seizure-associated neuronal injury. Ann. Neurol. 2017, 82, 115-120. [CrossRef]

20. Quinlan, S.M.M.; Rodriguez-Alvarez, N.; Molloy, E.J.; Madden, S.F.; Boylan, G.B.; Henshall, D.C.; Jimenez-Mateos, E.M. Complex spectrum of phenobarbital effects in a mouse model of neonatal hypoxia-induced seizures. Sci. Rep. 2018, 8, 9986. [CrossRef]

21. Bhardwaj, S.K.; Forcelli, P.A.; Palchik, G.; Gale, K.; Srivastava, L.K.; Kondratyev, A. Neonatal exposure to phenobarbital potentiates schizophrenia-like behavioral outcomes in the rat. Neuropharmacology 2012, 62, 2337-2345. [CrossRef] [PubMed]

22. Pisani, F.; Spagnoli, C. Neonatal seizures: A review of outcomes and outcome predictors. Neuropediatrics 2016, 47, 12-19. [CrossRef] [PubMed]

23. Maitre, N.L.; Smolinsky, C.; Slaughter, J.C.; Stark, A.R. Adverse neurodevelopmental outcomes after exposure to phenobarbital and levetiracetam for the treatment of neonatal seizures. J. Perinatol. Off. Calif. Perinat. Assoc. 2013, 33, 841-846. [CrossRef] [PubMed] 
24. Pressler, R.M.; Boylan, G.B.; Marlow, N.; Blennow, M.; Chiron, C.; Cross, J.H.; de Vries, L.S.; Hallberg, B.; Hellstrom-Westas, L.; Jullien, V.; et al. Bumetanide for the treatment of seizures in newborn babies with hypoxic ischaemic encephalopathy (NEMO): An open-label, dose finding, and feasibility phase 1/2 trial. Lancet Neurol. 2015, 14, 469-477. [CrossRef]

25. Shimomura, C.; Ohta, H. Behavioral abnormalities and seizure susceptibility in rat after neonatal anoxia. Brain Dev. 1988, 10, 160-163. [CrossRef]

26. Ujházy, E.; Schmidtová, M.; Dubovický, M.; Navarova, J.; Brucknerová, I.; Mach, M. Neurobehavioural changes in rats after neonatal anoxia: Effect of antioxidant stobadine pretreatment. Neuro. Endocrinol. Lett. 2006, 27, 82-85.

27. Samaiya, P.K.; Krishnamurthy, S. Characterization of mitochondrial bioenergetics in neonatal anoxic model of rats. J. Bioenerg. Biomembr. 2015, 47, 217-222. [CrossRef]

28. Coq, J.O.; Strata, F.; Russier, M.; Safadi, F.F.; Merzenich, M.M.; Byl, N.N.; Barbe, M.F. Impact of neonatal asphyxia and hind limb immobilization on musculoskeletal tissues and S1 map organization: Implications for cerebral palsy. Exp. Neurol. 2008, 210, 95-108. [CrossRef]

29. Rastogi, R.; Prichard, J.; Lowden, J. Elevation of phosphorus levels in serum and decreased brain content of gangliosides in rats following neonatal asphyxia. Pediatr. Res. 1968, 2, 125-130. [CrossRef]

30. Buwalda, B.; Nyakas, C.; Jan Vosselman, H.; Luiten, P.G.M. Effects of early postnatal anoxia on adult learning and emotion in rats. Behav. Brain Res. 1995, 67, 85-90. [CrossRef]

31. Rogalska, J.; Caputa, M.; Wentowska, K.; Nowakowska, A. Stress-induced behaviour in juvenile rats: Effects of neonatal asphyxia, body temperature and chelation of iron. Behav. Brain Res. 2004, 154, 321-329. [CrossRef] [PubMed]

32. Casolini, P.; Zuena, A.R.; Cinque, C.; Matteucci, P.; Alema', G.S.; Adriani, W.; Carpinelli, G.; Santoro, F.; Alleva, E.; Bosco, P.; et al. Sub-neurotoxic neonatal anoxia induces subtle behavioural changes and specific abnormalities in brain group-I metabotropic glutamate receptors in rats. J. Neurochem. 2005, 95, 137-145. [CrossRef] [PubMed]

33. Dell'Anna, M.E.; Calzolari, S.; Molinari, M.; Iuvone, L.; Calimici, R. Neonatal anoxia induces transitory hyperactivity, permanent spatial memory deficits and CA1 cell density reduction in developing rats. Behav. Brain Res. 1991, 45, 125-134. [CrossRef]

34. Speiser, Z.; Uziel, J.; Defrin-Assa, R.; Gitter, S.; Urca, G. Different behavioral deficits are induced by anoxia/hypoxia in neonatal and senescent rats: Blockade by MK-801. Behav. Brain Res. 1991, 42, 181-186. [CrossRef]

35. Iuvone, L.; Concetta Geloso, M.; Dell'Anna, E. Changes in open field behavior, spatial memory, and hippocampal parvalbumin immunoreactivity following enrichment in rats exposed to neonatal anoxia. Exp. Neurol. 1996, 139, 25-33. [CrossRef] [PubMed]

36. Tang, Y.; Pacary, E.; Freret, T.; Divoux, D.; Petit, E.; Schumann-Bard, P.; Bernaudin, M. Effect of hypoxic preconditioning on brain genomic response before and following ischemia in the adult mouse: Identification of potential neuroprotective candidates for stroke. Neurobiol. Dis. 2006, 21, 18-28. [CrossRef] [PubMed]

37. Rogalska, J.; Danielisova, V.; Caputa, M. Effect of neonatal body temperature on postanoxic, potentially neurotoxic iron accumulation in the rat brain. Neurosci. Lett. 2006, 393, 249-254. [CrossRef]

38. Takada, S.; Haemmerle, C.D.S.; Motta-Teixeira, L.; Machado-Nils, A.; Lee, V.; Takase, L.; Cruz-Rizzolo, R.; Kihara, A.; Xavier, G.; Watanabe, I.-S.; et al. Neonatal anoxia in rats: Hippocampal cellular and subcellular changes related to cell death and spatial memory. Neuroscience 2015, 284, 247-259. [CrossRef]

39. Takada, S.; Motta-Teixeira, L.C.; Machado-Nils, A.V.; Lee, V.Y.; Sampaio, C.A.; Polli, R.S.; Malheiros, J.M.; Takase, L.F.; Kihara, A.H.; Covolan, L.; et al. Impact of neonatal anoxia on adult rat hippocampal volume, neurogenesis and behavior. Behav. Brain Res. 2016, 296, 331-338. [CrossRef]

40. Speiser, Z.; Katzir, O.; Rehavi, M.; Zabarski, T.; Cohen, S. Sparing by rasagiline (TVP-1012) of cholinergic functions and behavior in the postnatal anoxia rat. Pharmacol. Biochem. Behav. 1998, 60, 387-393. [CrossRef]

41. Wasterlain, C.G. Does anoxemia play a role in the effects of neonatal seizures on brain growth? An experimental study in the rat. Eur. Neurol. 1979, 18, 222-229. [CrossRef] [PubMed]

42. Blaise, S.A.; Nédélec, E.; Alberto, J.M.; Schroeder, H.; Audonnet, S.; Bossenmeyer-Pourié, C.; Guéant, J.L.; Daval, J.L. Short hypoxia could attenuate the adverse effects of hyperhomocysteinemia on the developing rat brain by inducing neurogenesis. Exp. Neurol. 2009, 216, 231-238. [CrossRef] [PubMed] 
43. Martin, R.; Mozet, C.; Martin, H.; Welt, K.; Engel, C.; Fitzl, G. The effect of Ginkgo biloba extract (EGb 761) on parameters of oxidative stress in different regions of aging rat brains after acute hypoxia. Aging Clin. Exp. Res. 2011, 23, 255-263. [CrossRef] [PubMed]

44. Paulose, C.S.; Chathu, F.; Khan, S.R.; Krishnakumar, A. Neuroprotective role of Bacopa monnieri extract in epilepsy and effect of glucose supplementation during hypoxia: Glutamate receptor gene expression. Neurochem. Res. 2008, 33, 1663-1671. [CrossRef] [PubMed]

45. Anju, T.R.; Abraham, P.M.; Antony, S.; Paulose, C.S. Alterations in cortical GABAB receptors in neonatal rats exposed to hypoxic stress: Role of glucose, oxygen, and epinephrine resuscitation. Mol. Cell Biochem. 2010, 343, 1-11. [CrossRef]

46. Raveendran, A.T.; Skaria, P.C. Learning and cognitive deficits in hypoxic neonatal rats intensified by BAX mediated apoptosis: Protective role of glucose, oxygen, and epinephrine. Int. J. Neurosci. 2013, 123, 80-88. [CrossRef]

47. Jensen, F.E.; Alvarado, S.; Firkusny, I.R.; Geary, C. NBQX blocks the acute and late epileptogenic effects of perinatal hypoxia. Epilepsia 1995, 36, 966-972. [CrossRef]

48. Wang, C.T.; Lin, H.J.; Cheng, B.C.; Lin, M.T.; Chang, C.P. Attenuating systemic inflammatory markers in simulated high-altitude exposure by heat shock protein 70-mediated hypobaric hypoxia preconditioning in rats. J. Formos. Med. Assoc. 2015, 114, 328-338. [CrossRef]

49. Applegate, C.D.; Jensen, F.; Burchfiel, J.L.; Lombroso, C. The effects of neonatal hypoxia on kindled seizure development and electroconvulsive shock profiles. Epilepsia 1996, 37, 723-727. [CrossRef]

50. Mikati, M.A.; Zeinieh, M.P.; Kurdi, R.M.; Harb, S.A.; El Hokayem, J.A.; Daderian, R.H.; Shamseddine, A.; Obeid, M.; Bitar, F.F.; El Sabban, M. Long-term effects of acute and of chronic hypoxia on behavior and on hippocampal histology in the developing brain. Brain Res. Dev. Brain Res. 2005, 157, 98-102. [CrossRef]

51. Sampath, D.; Shmueli, D.; White, A.M.; Raol, Y.H. Flupirtine effectively prevents development of acute neonatal seizures in an animal model of global hypoxia. Neurosci. Lett. 2015, 607, 46-51. [CrossRef] [PubMed]

52. Mikati, M.A.; Hokayem, J.A.E.; Sabban, M.E.E. Effects of a single dose of erythropoietin on subsequent seizure susceptibility in rats exposed to acute hypoxia at P10. Epilepsia 2007, 48, 175-181. [CrossRef] [PubMed]

53. Peng, Z.; Li, J.; Li, Y.; Yang, X.; Feng, S.; Han, S.; Li, J. Downregulation of miR-181b in mouse brain following ischemic stroke induces neuroprotection against ischemic injury through targeting heat shock protein A5 and ubiquitin carboxyl-terminal hydrolase isozyme L1. J. Neurosci. Res. 2013, 91, 1349-1362. [CrossRef] [PubMed]

54. Greggio, S.; Rosa, R.M.; Dolganov, A.; de Oliveira, I.M.; Menegat, F.D.; Henriques, J.A.; DaCosta, J.C. NAP prevents hippocampal oxidative damage in neonatal rats subjected to hypoxia-induced seizures. Neurobiol. Dis. 2009, 36, 435-444. [CrossRef] [PubMed]

55. Zhang, C.P.; Zhu, L.L.; Zhao, T.; Zhao, H.; Huang, X.; Ma, X.; Wang, H.; Fan, M. Characteristics of neural stem cells expanded in lowered oxygen and the potential role of hypoxia-inducible factor-1Alpha. Neurosignals 2006, 15, 259-265. [CrossRef]

56. Aujla, P.K.; Fetell, M.R.; Jensen, F.E. Talampanel suppresses the acute and chronic effects of seizures in a rodent neonatal seizure model. Epilepsia 2009, 50, 694-701. [CrossRef]

57. Rakhade, S.N.; Klein, P.M.; Huynh, T.; Hilario-Gomez, C.; Kosaras, B.; Rotenberg, A.; Jensen, F.E. Development of later life spontaneous seizures in a rodent model of hypoxia-induced neonatal seizures. Epilepsia 2011, 52, 753-765. [CrossRef]

58. Sanchez, R.M.; Ribak, C.E.; Shapiro, L.A. Synaptic connections of hilar basal dendrites of dentate granule cells in a neonatal hypoxia model of epilepsy. Epilepsia 2012, 53, 98-108. [CrossRef]

59. Mikhailenko, V.A.; Butkevich, I.P.; Bagaeva, T.R.; Makukhina, G.V.; Otellin, V.A. Short- and long-term influences of hypoxia during early postnatal period of development on behavioral and hormonal responses in rats. Neurosci. Lett. 2009, 464, 214-217. [CrossRef]

60. Koh, S.; Jensen, F.E. Topiramate blocks perinatal hypoxia-induced seizures in rat pups. Ann. Neurol. 2001, 50, 366-372. [CrossRef]

61. Laroia, N.; McBride, L.; Baggs, R.; Guillet, R. Dextromethorphan ameliorates effects of neonatal hypoxia on brain morphology and seizure threshold in rats. Dev. Brain Res. 1997, 100, 29-34. [CrossRef]

62. Rotstein, M.; Bassan, H.; Kariv, N.; Speiser, Z.; Harel, S.; Gozes, I. NAP enhances neurodevelopment of newborn apolipoprotein E-deficient mice subjected to hypoxia. J. Pharmacol. Exp. Ther. 2006, 319, 332-339. [CrossRef] 
63. Decker, M.J.; Hue, G.; Caudle, W.; Miller, G.; Keating, G.; Rye, D. Episodic neonatal hypoxia evokes executive dysfunction and regionally specific alterations in markers of dopamine signaling. Neuroscience 2003, 117, 417-425. [CrossRef]

64. Mortola, J.P.; Naso, L. Thermogenesis in newborn rats after prenatal or postnatal hypoxia. J. Appl. Physiol. 1998, 85, 84-90. [CrossRef] [PubMed]

65. Decker, M.J.; Jones, K.A.; Solomon, I.G.; Keating, G.L.; Rye, D.B. Reduced extracellular dopamine and increased responsiveness to novelty: Neurochemical and behavioral sequelae of intermittent hypoxia. Sleep 2005, 28, 169-176. [CrossRef]

66. Caputa, M.; Rogalska, J.; Wentowska, K.; Nowakowska, A. Perinatal asphyxia, hyperthermia and hyperferremia as factors inducing behavioural disturbances in adulthood: A rat model. Behav. Brain Res. 2005, 163, 246-256. [CrossRef]

67. Zanelli, S.; Goodkin, H.P.; Kowalski, S.; Kapur, J. Impact of transient acute hypoxia on the developing mouse EEG. Neurobiol. Dis. 2014, 68, 37-46. [CrossRef]

68. Wang, K.C.; Fan, L.W.; Kaizaki, A.; Pang, Y.; Cai, Z.; Tien, L.T. Neonatal lipopolysaccharide exposure induces long-lasting learning impairment, less anxiety-like response and hippocampal injury in adult rats. Neuroscience 2013, 234, 146-157. [CrossRef]

69. Hagberg, H.; Mallard, C.; Ferriero, D.M.; Vannucci, S.J.; Levison, S.W.; Vexler, Z.S.; Gressens, P. The role of inflammation in perinatal brain injury. Nat. Rev. Neurol. 2015, 11, 192-208. [CrossRef]

70. Mallard, C.; Tremblay, M.E.; Vexler, Z.S. Microglia and Neonatal Brain Injury. Neuroscience 2019, 1,68-76. [CrossRef]

71. Takemiya, T.; Fumizawa, K.; Yamagata, K.; Iwakura, Y.; Kawakami, M. Brain Interleukin-1 facilitates learning of a water maze spatial memory task in young mice. Front. Behav. Neurosci. 2017, 11, 202. [CrossRef] [PubMed]

72. Al Mamun, A.; Yu, H.; Romana, S.; Liu, F. Inflammatory responses are sex specific in chronic hypoxic-ischemic encephalopathy. Cell Transplant. 2018, 1328-1339. [CrossRef] [PubMed]

73. Manuck, T.A.; Rice, M.M.; Bailit, J.L.; Grobman, W.A.; Reddy, U.M.; Wapner, R.J.; Thorp, J.M.; Caritis, S.N.; Prasad, M.; Tita, A.T.N. Preterm neonatal morbidity and mortality by gestational age: A contemporary cohort. Am. J. Obstet. Gynecol. 2016, 215, e101-e114. [CrossRef] [PubMed]

74. Schmidt, J.W.; Walsh, W.F. Hypoxic-ischemic encephalopathy in preterm infants. J. Neonatal. Perinatal. Med. 2010, 3, 277-284. [CrossRef]

75. Chalak, L.F.; Rollins, N.; Morriss, M.C.; Brion, L.P.; Heyne, R.; Sanchez, P.J. Perinatal acidosis and hypoxic-ischemic encephalopathy in preterm infants of 33 to 35 weeks' gestation. J. Pediatr. 2012, 160, 388-394. [CrossRef]

76. Garfinkle, J.; Wintermark, P.; Shevell, M.I.; Oskoui, M. Children born at 32 to 35 weeks with birth asphyxia and later cerebral palsy are different from those born after 35 weeks. J. Perinatol. 2017, 37, 963-968. [CrossRef]

77. Woodward, L.J.; Anderson, P.J.; Austin, N.C.; Howard, K.; Inder, T.E. Neonatal MRI to predict neurodevelopmental outcomes in preterm infants. N. Engl. J. Med. 2006, 355, 685-694. [CrossRef]

78. Batalle, D.; Eixarch, E.; Figueras, F.; Muoz-Moreno, E.; Bargallo, N.; Illa, M.; Acosta-Rojas, R.; Amat-Roldan, I.; Gratacos, E. Altered smallworld topology of structural brain networks in infants with intrauterine growth restriction and its association with later neurodevelopmental outcome. NeuroImage 2012, 60, 1352-1366. [CrossRef]

79. Mullen, K.M.; Vohr, B.R.; Katz, K.H.; Schneider, K.C.; Lacadie, C.; Hampson, M.; Makuch, R.W.; Reiss, A.L.; Constable, R.T.; Ment, L.R. Preterm birth results in alterations in neural connectivity at age 16 years. NeuroImage 2011, 54, 2563-2570. [CrossRef]

80. Buser, J.R.; Maire, J.; Riddle, A.; Gong, X.; Nguyen, T.; Nelson, K.; Luo, N.L.; Ren, J.; Struve, J.; Sherman, L.S. Arrested preoligodendrocyte maturation contributes to myelination failure in premature infants. Ann. Neurol. 2012, 71, 93-109. [CrossRef]

81. Bartha, A.I.; Foster-Barber, A.; Miller, S.P.; Vigneron, D.B.; Glidden, D.V.; Barkovich, A.J.; Ferriero, D.M. Neonatal encephalopathy: Association of cytokines with MR spectroscopy and outcome. Pediatr. Res. 2004, 56, 960-966. [CrossRef] [PubMed]

82. Zindel, J.; Kubes, P. DAMPs, PAMPs, and LAMPs in immunity and sterile inflammation. Annu. Rev. Pathol. Mech. Dis. 2020, 15, 493-518. [CrossRef] [PubMed] 
83. Serdar, M.; Kempe, K.; Rizazad, M.; Herz, J.; Bendix, I.; Felderhoff-Müser, U.; Sabir, H. Early pro-inflammatory microglia activation after inflammation-sensitized hypoxic-ischemic brain injury in neonatal rats. Front. Cell Neurosci. 2019, 13, 237. [CrossRef] [PubMed]

84. Lalancette-Hébert, M.; Faustino, J.; Sampath Thammisetty, S.; Chip, S.; Vexler, Z.S.; Kriz, J. Live imaging of the innate immune response in neonates reveals differential TLR2 dependent activation patterns in sterile inflammation and infection. Brain Behav. Immun. 2017, 65, 312-327. [CrossRef]

85. Stridh, L.; Smith, P.L.; Naylor, A.S.; Wang, X.; Mallard, C. Regulation of Toll-like receptor 1 and -2 in neonatal mice brains after hypoxia-ischemia. J. Neuroinflammation 2011, 8, 45. [CrossRef]

86. Mottahedin, A.; Ardalan, M.; Chumak, T.; Riebe, I.; Ek, J.; Mallard, C. Effect of neuroinflammation on synaptic organization and function in the developing brain: Implications for neurodevelopmental and neurodegenerative disorders. Front. Cell. Neurosci. 2017, 11, 190. [CrossRef]

87. Tang, Z.; Cheng, S.; Sun, Y.; Zhang, Y.; Xiang, X.; Ouyang, Z.; Zhu, X.; Wang, B.; Hei, M. Early TLR4 inhibition reduces hippocampal injury at puberty in a rat model of neonatal hypoxic-ischemic brain damage via regulation of neuroimmunity and synaptic plasticity. Exp. Neurol. 2019, 321, 113039. [CrossRef]

88. Burnstock, G. Purinergic signalling and disorders of the central nervous system. Nat. Rev. Drug Dis. 2008, 7, 575-590. [CrossRef]

89. Burnstock, G. Physiology and pathophysiology of purinergic neurotransmission. Physiol. Rev. 2007, 87, 659-797. [CrossRef]

90. Sperlagh, B.; Illes, P. P2X7 receptor: An emerging target in central nervous system diseases. Trend Pharmacol. Sci. 2014, 35, 537-547. [CrossRef]

91. Rappold, P.M.; Lynd-Balta, E.; Joseph, S.A. P2X7 receptor immunoreactive profile confined to resting and activated microglia in the epileptic brain. Brain Res. 2006, 1089, 171-178. [CrossRef] [PubMed]

92. Mingam, R.; De Smedt, V.; Amedee, T.; Bluthe, R.M.; Kelley, W.K.; Dantzer, R.; Laye, S. In vitro and in vivo evidence for a role of the P2X7 receptor in the release of IL-1 beta in the murine brain. Brain Behav. Immun. 2008, 22, 234-244. [CrossRef] [PubMed]

93. Monif, M.; Reid, C.A.; Powell, K.L.; Smart, M.L.; Williams, D.A. The P2X7 receptor drives microglial activation and proliferation: A trophic role for P2X7R pore. J. Neurosci. 2009, 29, 3781-3791. [CrossRef] [PubMed]

94. Armstrong, J.N.; Brust, T.B.; Lewis, R.G.; MacVicar, B.A. Activation of presynaptic P2X7-like receptors depresses mossy fiber-CA3 synaptic transmission through p38 mitogen-activated protein kinase. J. Neurosci. 2002, 22, 5938-5945. [CrossRef]

95. Sperlagh, B.; Köfalvi, A.; Deuchars, J.; Atkinson, L.; Milligan, C.J.; Buckley, N.J.; Vizi, E.S. Involvement of $\mathrm{P} 2 \mathrm{X} 7$ receptors in the regulation of neurotransmitter release in the rat hippocampus. J. Neurochem. 2002, 81, 1196-1211. [CrossRef]

96. Dale, N.; Frenguelli, B.G. Release of adenosine and ATP during ischemia and epilepsy. Curr. Neuropharmacol. 2009, 7, 160-179. [CrossRef]

97. Ulrich, H.; Illes, P. P2X receptors in maintenance and differentiation of neural progenitor cells. Neural. Regen. Res. 2014, 9, 2040-2041. [CrossRef]

98. Illes, P.; Messemer, N.; Rubini, P. P2Y receptors in neurogenesis. WIRES Membr. Transp. Signal 2013, 2, 43-48. [CrossRef]

99. Rozmer, K.; Gao, P.; Araújo, M.G.L.; Tahir Khan, M.; Liu, J.; Rong, W.; Tang, Y.; Franke, H.; Krügel, U.; Fernandes, M.J.S.; et al. Pilocarpine-Induced Status Epilepticus Increases the Sensitivity of P2X7 and P2Y1 Receptors to Nucleotides at Neural Progenitor Cells of the Juvenile Rodent Hippocampus. Cereb. Cortex 2017, 27, 3568-3585. [CrossRef]

100. Mesuret, G.; Engel, T.; Hessel, E.V.; Sanz-Rodriguez, A.; Jimenez-Pacheco, A.; Miras-Portugal, M.T.; Diaz-Hernandez, M.; Henshall, D.C. P2X7 receptor inhibition interrupts the progression of seizures in immature rats and reduces hippocampal damage. CNS Neurosci. Ther. 2014, 20, 556-564. [CrossRef]

101. Tsimis, M.E.; Lei, J.; Rosenzweig, J.M.; Arif, H.; Shabi, Y.; Alshehri, W.; Talbot, C.C.; Baig-Ward, K.M.; Segars, J.; Graham, E.M.; et al. P2X7 receptor blockade prevents preterm birth and perinatal brain injury in a mouse model of intrauterine inflammation. Biol. Reprod. 2017, 97, 230-239. [CrossRef] [PubMed]

102. Da Silva, C.S.; Longoni Calió, M.; Mosini, A.C.; Moreira Pires, J.; da Silva Bandeira Rêgo, D.; Mello, L.E.; Figueiredo Stochero Leslie, A.T. LPS-Induced systemic neonatal inflammation: Blockage of P2X7R by BBG decreases mortality on rat pups and oxidative stress in hippocampus of adult rats. Front. Behav. Neurosci. 2019, 13, 240. [CrossRef] [PubMed] 
103. Jenkins, D.D.; Rollins, L.G.; Perkel, J.K.; Wagner, C.L.; Katikaneni, L.P.; Bass, W.T.; Kaufman, D.A.; Horgan, M.J.; Languani, S.; Givelichian, L.; et al. Serum cytokines in a clinical trial of hypothermia for neonatal hypoxic-ischemic encephalopathy. J. Cereb. Blood Flow Metab. 2012, 32, 1888-1896. [CrossRef] [PubMed]

104. Liu, J.; Feng, Z.C. Increased umbilical cord plasma interleukin-1 beta levels was correlated with adverse outcomes of neonatal hypoxic-ischemic encephalopathy. J. Trop. Pediatr. 2010, 56, 178-182. [CrossRef] [PubMed]

105. Liu, F.; Mccullough, L.D. Inflammatory responses in hypoxic ischemic encephalopathy. Acta Pharmacol. Sin. 2013, 34, 1121-1130. [CrossRef] [PubMed]

106. Bona, E.; Andersson, A.L.; Blomgren, K.; Gilland, E.; Puka-Sundvall, M.; Gustafson, K.; Hagberg, H. Chemokine and inflammatory cell response to hypoxia-ischemia in immature rats. Pediatr. Res. 1999, 45, 500-509. [CrossRef]

107. Winerdal, M.; Winerdal, M.E.; Kinn, J.; Urmaliya, V.; Winqvist, O.; Ådén, U. Long lasting local and systemic inflammation after cerebral hypoxic ischemia in newborn mice. PLoS ONE 2012, 7, e36422. [CrossRef]

108. Sofroniew, M.V. Molecular dissection of reactive astrogliosis and glial scar formation. Trends Neurosci. 2009, 32, 638-647. [CrossRef]

109. Verkhratsky, A.; Sofroniew, M.V.; Messing, A.; deLanerolle, N.C.; Rempe, D.; Rodríguez, J.J.; Nedergaard, M. Neurological diseases as primary gliopathies: A reassessment of neurocentrism. ASN Neuro 2012. [CrossRef]

110. Johnston, M.V.; Fatemi, A.; Wilson, M.A.; Northington, F. Treatment advances in neonatal neuroprotection and neurointensive care. Lancet Neurol. 2011, 10, 372-382. [CrossRef]

111. Morken, T.S.; Brekke, E.; Håberg, A.; Widerøe, M.; Brubakk, A.-M.; Sonnewald, U. Altered astrocyte-neuronal interactions after hypoxia-ischemia in the neonatal brain in female and male rats. Stroke 2014, 45, 2777-2785. [CrossRef]

112. Wang, X.; Yang, X.-L.; Kong, W.-L.; Zeng, M.-L.; Shao, L.; Jiang, G.-T.; Cheng, J.-J.; Kong, S.; He, X.-H.; Liu, W.-H.; et al. TRPV1 translocated to astrocytic membrane to promote migration and inflammatory infiltration thus promotes epilepsy after hypoxic ischemia in immature brain. J. Neuroinflammation 2019, 16, 214. [CrossRef] [PubMed]

113. Hurtado-Zavala, J.I.; Ramachandran, B.; Ahmed, S.; Halder, R.; Bolleyer, C.; Awasthi, A.; Stahlberg, M.A.; Wagener, R.J.; Anderson, K.R.; Drenan, R.M.; et al. TRPV1 regulates excitatory innervation of OLM neurons in the hippocampus. Nat. Commun. 2017, 8, 15878. [CrossRef]

114. He, M.L.; Lv, Z.Y.; Shi, X.; Yang, T.; Zhang, Y.; Li, T.-Y.; Chen, J. Interleukin-10 release from astrocytes suppresses neuronal apoptosis via the TLR2/NFKB pathway in a neonatal rat model of hypoxic-ischemic brain damage. J. Neurochem. 2017, 142, 920-933. [CrossRef] [PubMed]

115. Jiao, M.; Li, X.; Chen, L.; Wang, X.; Yuan, B.; Liu, T. Neuroprotective effect of astrocyte-derived IL-33 in neonatal hypoxic-ischemic brain injury. J. Neuroinflammation 2020, 17, 251. [CrossRef] [PubMed]

116. Gu, Y.; He, M.; Zhou, X.; Liu, J.; Hou, N.; Bin, T.; Zhang, Y.; Li, T.; Chen, J. Endogenous IL-6 of mesenchymal stem cell improves behavioral outcome of hypoxic-ischemic brain damage neonatal rats by supressing apoptosis in astrocyte. Sci. Rep. 2016, 6, 18587. [CrossRef]

117. He, M.; Shi, X.; Yang, M.; Yang, T.; Li, T.; Chen, J. Mesenchymal stem cells-derived IL-6 activates AMPK/mTOR signaling to inhibit the proliferation of reactive astrocytes induced by hypoxic-ischemic brain damage. Exp. Neurol. 2019, 311, 15-32. [CrossRef]

118. Montaldo, P.; Ivain, P.; Lally, P.; Bassett, P.; Pant, S.; Oliveira, V. White matter injury after neonatal encephalopathy is associated with thalamic metabolite perturbations. EBioMedicine 2020, 52, 102663. [CrossRef]

119. Haynes, R.L.; Folkerth, R.D.; Keefe, R.J.; Sung, I.; Swzeda, L.I.; Rosenberg, P.A.; Volpe, J.J.; Kinney, H.C. Nitrosative and oxidative injury to premyelinating oligodendrocytes in periventricular Leukomalacia. J. Neuropathol. Exp. Neurol. 2003, 62, 441-450. [CrossRef]

120. Billiards, S.S.; Haynes, R.L.; Folkerth, R.D.; Borenstein, N.S.; Trachtenberg, F.L.; Rowitch, D.H.; Ligon, K.L.; Volpe, J.J.; Kinney, H.C. Myelin abnormalities without oligodendrocyte loss in periventricular Leukomalacia. Brain Pathol. 2008, 18, 153-163. [CrossRef]

121. Favrais, G.; van de Looij, Y.; Fleiss, B.; Ramanantsoa, N.; Bonnin, P.; Stoltenburg-Didinger, G. Systemic inflammation disrupts the developmental program of white matter. Ann. Neurol. 2011, 70, 550-565. [CrossRef] [PubMed] 
122. Val, A.; Ferrario, M.; Dreano, M.; Garotta, G.; Spano, P.; Pizzi, M. Soluble Interleukin-6 (IL-6) Receptor/IL-6 fusion protein enhances in vitro differentiation of purified rat oligodendroglial lineage cells. Mol. Cell. Neurosci. 2002, 21, 602-615.

123. Campbell, I.L.; Abraham, C.R.; Masliah, E.; Kemper, P.; Inglis, J.D.; Oldstone, M.B.; Mucke, L. Neurologic disease induced in transgenic mice by cerebral overexpression of interleukin 6. Proc. Natl. Acad. Sci. USA 1993, 90, 10061-10065. [CrossRef] [PubMed]

124. Lai, J.C.Y.; Rocha-Ferreira, E.; Ek, C.J.; Wang, X.; Hagberg, H.; Mallard, C. Immune responses in perinatal brain injury. Brain Behav. Immun. 2016, 63, 210-223. [CrossRef]

125. Martín-Ancel, A.; García-Alix, A.; Salas, S.; Castillo F del Cabañas, F.; Quero, J. Cerebrospinal fluid leucocyte counts in healthy neonates. Arch. Dis. Child. Neonatal Ed. 2006, 91, F357-F358. [CrossRef]

126. Hedtjärn, M.; Mallard, C.; Hagberg, H. Inflammatory Gene Profiling in the Developing Mouse Brain after Hypoxia-Ischemia. J. Cereb. Blood Flow Metab. 2004, 24, 1333-1551. [CrossRef]

127. Shi, C.; Pamer, E.G. Monocyte recruitment during infection and inflammation. Nat. Rev. Immunol. 2011, 11, 762-774. [CrossRef]

128. Palmer, C.; Roberts, R.L.; Young, P.I. Timing of neutrophil depletion influences long-term neuroprotection in neonatal rat hypoxic-ischemic brain injury. Pediatr. Res. 2004, 55, 549-556. [CrossRef]

129. Mesplès, B.; Fontaine, R.H.; Lelièvre, V.; Launay, J.-M.; Gressens, P. Neuronal TGF-beta1 mediates IL-9/mast cell interaction and exacerbates excitotoxicity in newborn mice. Neurobiol. Dis. 2005, 18, 193-205. [CrossRef]

130. Jin, Y.; Silverman, A.-J.; Vannucci, S.J. Mast cell stabilization limits hypoxic-ischemic brain damage in the immature rat. DNE 2007, 29, 373-384. [CrossRef]

131. Jin, Y.; Silverman Ann, J.; Vannucci Susan, J. Mast cells are early responders after hypoxia-ischemia in immature rat brain. Stroke 2009, 40, 3107-3112. [CrossRef] [PubMed]

132. Smith, P.L.P.; Mottahedin, A.; Svedin, P.; Mohn, C.-J.; Hagberg, H.; Ek, J.; Mallard, C. Peripheral myeloid cells contribute to brain injury in male neonatal mice. J. Neuroinflammation 2018, 15, 301. [CrossRef] [PubMed]

133. Albertsson, A.-M.; Bi, D.; Duan, L.; Zhang, X.; Leavenworth, J.W.; Qiao, L.; Zhu, C.; Cardell, S.; Cantor, H.; Hagberg, H.; et al. The immune response after hypoxia-ischemia in a mouse model of preterm brain injury. J. Neuroinflammation 2014, 11, 153. [CrossRef] [PubMed]

Publisher's Note: MDPI stays neutral with regard to jurisdictional claims in published maps and institutional affiliations.

(C) 2020 by the authors. Licensee MDPI, Basel, Switzerland. This article is an open access article distributed under the terms and conditions of the Creative Commons Attribution (CC BY) license (http://creativecommons.org/licenses/by/4.0/). 